\title{
Effect of testosterone oenanthate on spermatogenesis and serum testosterone concentrations in adult mice
}

\author{
M. R. Bansal* and A. G. Davies \\ Department of Physiology, The Medical School, University of Birmingham, Birmingham, U.K.
}

\begin{abstract}
Summary. Administration of 80 or $160 \mu$ g testosterone oenanthate s.c. three times per week for 8 or 12 weeks reduced testis weight and increased seminal vesicle weight in mice. Radioimmunoassay indicated that treatment increased serum testosterone concentrations. Treatment with testosterone oenanthate decreased the number of step 16 and step 7 spermatids, pachytene spermatocytes and type A spermatogonia, and particularly reduced the proportion of step 7 spermatids which matured to form step 16 spermatids.
\end{abstract}

\section{Introduction}

Testosterone in relatively small doses inhibits secretion of gonadotrophins and thus suppresses spermatogenesis (Reddy \& Rao, 1972; Desjardins, Ewing \& Irby, 1973; Ewing, Stratton \& Desjardins, 1973; Berndtson, Desjardins \& Ewing, 1974; Steinberger \& Smith, 1977). However, large doses of testosterone stimulate spermatogenesis, even though pituitary gonadotrophin secretion is depressed (Nelson \& Merckel, 1937; Ludwig, 1950; Clermont \& Harvey, 1967). The reason that low doses of testosterone, adequate to maintain the accessory sex glands and libido, is insufficient to maintain spermatogenesis lies in the anatomical location of the seminiferous tubules close to the source of endogenous testosterone in the Leydig cells. The seminiferous epithelium is normally exposed to a much greater concentration of testosterone than the rest of the body, and this is not replaced by administration of amounts of hormone sufficient to stimulate other androgen-dependent tissues (Heller, Morse, Su \& Rowley, 1970; Walsh \& Swerdloff, 1973). For the present investigations low doses of testosterone oenanthate were used to investigate the effects on serum testosterone and spermatogenesis.

\section{Material and Methods}

Adult male LACA mice (Olac, Blackthorn, Bicester, U.K.) were used. Testosterone oenanthate (Primoteston Depot, Schering, FRG) was administered three times a week s.c. in $0 \cdot 1 \mathrm{ml}$ sesame oil to mice aged 8 weeks in doses of $0,40,80$ or $160 \mu \mathrm{g}$ for 8 or 12 weeks. For the mice treated for 12 weeks the dose was doubled in the last 4 weeks to $0,80,160$ or $320 \mu \mathrm{g}$ to achieve greater suppression of spermatogenesis. Animals were killed on the day after the last injection of testosterone oenanthate by decapitation under anaesthesia and blood was allowed to drip from the severed neck. The serum was removed by centrifugation from the clotted blood and stored at $-20^{\circ} \mathrm{C}$ until used for radioimmunoassay (RIA) of testosterone. The following reagents were used: $\left[1,2,6,7-{ }^{3} \mathrm{H}\right]$ testosterone (sp. act. $94 \mathrm{Ci} / \mathrm{mmol}$ : Amersham, Bucks, U.K.), anti-testosterone antiserum (Guildhay, Surrey, U.K.; antiserum HP/S/51-1A), testosterone (Sigma Chemicals, U.S.A.) and dextran-coated charcoal.

*Present address: Department of Biophysics, Panjab University, Chandigarh 160014, India. 
To measure testosterone by RIA $0.2 \mathrm{ml}$ serum samples were extracted with $1 \mathrm{ml}$ diethyl ether. The extract was evaporated and incubated with $0.1 \mathrm{ml}$ antiserum and $0.1 \mathrm{ml}$ tritiated testosterone. A dextran-coated charcoal suspension $(0.5 \mathrm{ml})$ in phosphate buffer $(0.005 \mathrm{M}, \mathrm{pH} 7.0)$ was used to separate the bound and free steroid, and, after centrifugation at $4{ }^{\circ} \mathrm{C}$, the supernatant was removed for measurement of ${ }^{3} \mathrm{H}$-radioactivity in the bound fraction. Blank assay tubes were also run.

The detection limit ( $2 \times$ s.d. at zero dose) was approximately $3 \mathrm{pg}$ and the cross-reactivity with other steroids in the assay was negligible. The ratio of the c.p.m. bound in the absence of unlabelled steroid $(\mathrm{Co})$ and the c.p.m. bound in the presence of standard $(\mathrm{Cx})$ was plotted versus standard. From $\mathrm{Co} / \mathrm{Cx}$ values for the unknown samples the number of $\mathrm{pg}$ testosterone were read from the above standard curve.

The testis was dissected out, weighed and fixed in Bouin-Hollande fixative for $48 \mathrm{~h}$; to ensure complete fixation a cut was made into the testis. The testis was embedded in paraplast wax after routine dehydration. Ribbons of sections, $4 \mu \mathrm{m}$ thick (Leitz Wetzler microtome), were stained by the periodic acid-Schiff reaction (McManus, 1946) and counter-stained in Harris's haematoxylin and mounted in DPX.

Counts were made of cell nuclei lying in transverse sections of tubules at stage VII of the cycle of the seminiferous epithelium (Leblond \& Clermont, 1952; Oakberg, 1956). Nuclei of Sertoli cells and type A spermatogonia were scored only when nucleoli were visible. Sections of tubules not showing a lumen or having axial ratios greater than 2 were not used. Attempts to count all the fragments of a particular type of particle present in microtome sections led to an underestimate of the number of particles because the smallest fragments (the polar caps) were either unrecognizable or too thin to be seen (Davies, Courot \& Gresham, 1974). This error was reduced by counting sections of nuclei or nucleoli whose apparent diameter was judged to be larger than the true radius. A correction for the size of the diameter was then made by a modification of Abercrombie's method (Davies, 1973).

\section{Results}

One-way analyses of variance on data from all 5 treatment groups indicated significant effects on testis $(P<0.001)$ and seminal vesicle weight $(P<0.01)$. Treatment for 12 weeks with 80 and $160 \mu \mathrm{g}$ doses of testosterone oenanthate reduced testis weight by $30 \%$ (Table 1 ) but caused a $70 \%$ increase in the weight of the seminal vesicles. Testosterone oenanthate had no effect on body weight.

The serum testosterone concentration was increased significantly $(P<0.001)$ and showed a 3.5-fold increase in Groups C, D and E as compared with the control group (Table 1).

Table 1. Organ and body weights and serum testosterone concentration in LACA mice after treatment with testosterone oenanthate

\begin{tabular}{|c|c|c|c|c|c|c|}
\hline \multirow[b]{2}{*}{ Group } & \multirow{2}{*}{$\begin{array}{c}\text { Testosterone } \\
\text { oenanthate } \\
(\mu \mathrm{g})\end{array}$} & \multirow[b]{2}{*}{$\begin{array}{l}\text { Duration } \\
\text { (weeks) }\end{array}$} & \multirow[b]{2}{*}{$\begin{array}{l}\text { Body wt } \\
\text { (g) }\end{array}$} & \multicolumn{2}{|c|}{ Organ weight (mg) } & \multirow[b]{2}{*}{$\begin{array}{l}\text { Testosterone } \\
\text { (pg/ml serum) }\end{array}$} \\
\hline & & & & Testis & $\begin{array}{l}\text { Seminal } \\
\text { vesicle }\end{array}$ & \\
\hline A & 0 (control) & 0 & $35 \pm 0 \cdot 0$ & $82 \pm 4 \cdot 2$ & $82 \pm 8 \cdot 3$ & $205 \pm 12$ \\
\hline B & 80 & 8 & $36 \pm 0.8$ & $74 \pm 3.9 *$ & $88 \pm 5 \cdot 3$ & $386 \pm 59^{* * *}$ \\
\hline $\mathrm{C}$ & 160 & 8 & $35 \pm 0.5$ & $61 \pm 2 \cdot 9^{* * *}$ & $97 \pm 12.6$ & $917 \pm 77^{* * *}$ \\
\hline D & 80 & 12 & $34 \pm 2 \cdot 1$ & $57 \pm 2 \cdot 0^{* * * *}$ & $138 \pm 9 \cdot 4^{* * *}$ & $928 \pm 72^{* * *}$ \\
\hline E & 160 & 12 & $33 \pm 1 \cdot 4$ & $56 \pm 2 \cdot 1^{* * *}$ & $139 \pm 20 \cdot 1^{* * *}$ & $936 \pm 76^{* * *}$ \\
\hline
\end{tabular}

Values are mean \pm s.e.m. for 6 mice.

${ }^{*} P<0.05 ;{ }^{* *} P<0.01 ;{ }^{* * *} P<0.001$, compared with value for Group A (LSD on analyses of variance data). 

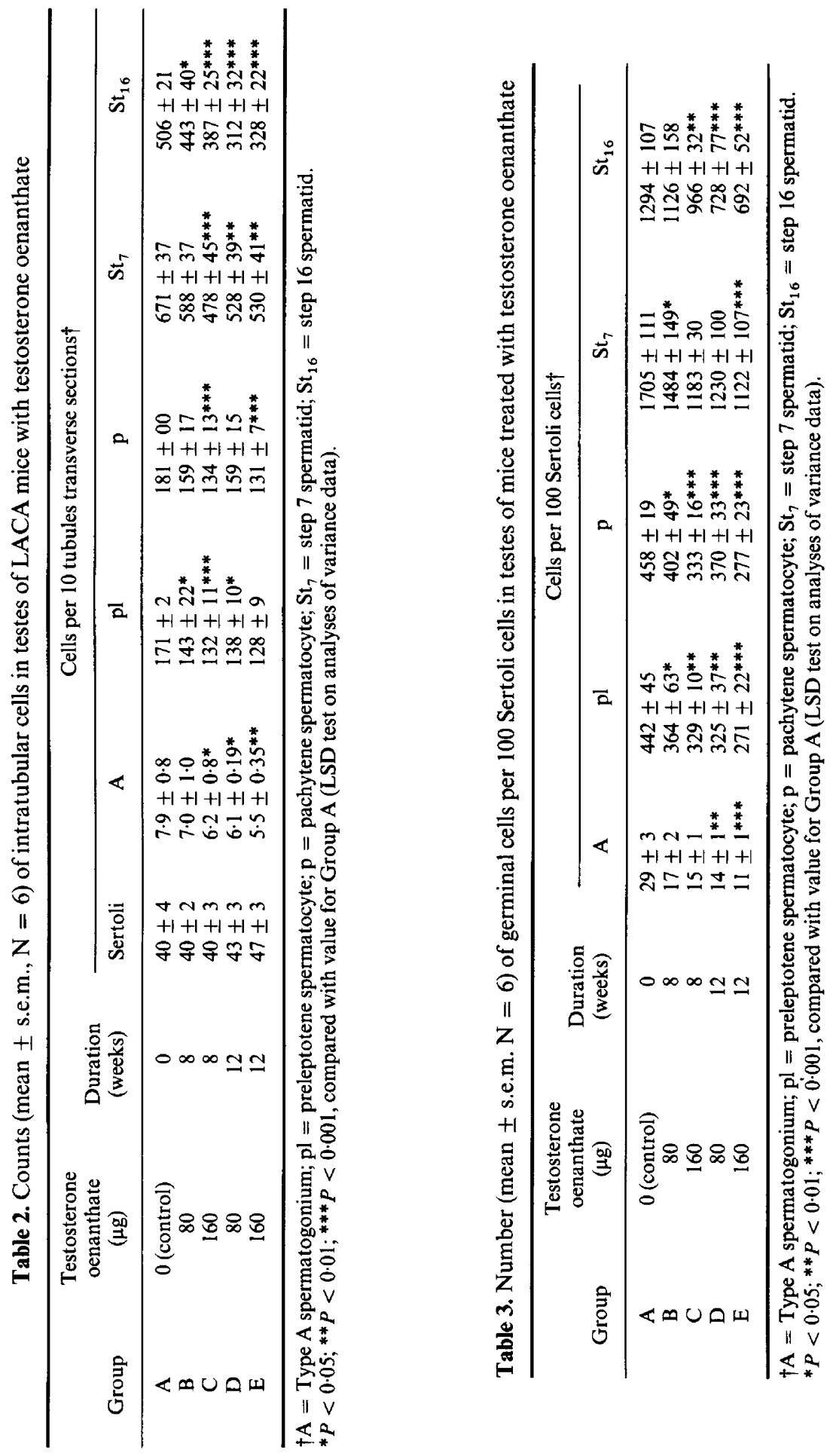
The corrected cell counts in 10 transverse sections of seminiferous tubules, after applying diameter corrections, are given in Table 2. The overall effect of testosterone oenanthate was significant on step $16(P<0.01)$ and step 7 spermatids $(P<0.05)$ as given by one-way analyses of variance on data from all the treatment groups. There were reductions in the number of step 16 and step 7 spermatids, pachytene and preleptotene spermatocytes and type A spermatogonia which were dependent both on the dose and the time of treatment. As might be expected the depression of intratubular germinal cell number was greater after 12 weeks of treatment than after 8 weeks.

The number of the Sertoli cells in the testis of an adult animal appears to be independent of changes in the hormonal environment, so the larger number of Sertoli cells per 10 tubules sections in Group E was presumably due to shrinkage of the tubules (Clermont \& Morgentaler, 1955; Bustos-Obregon, 1970). To correct for this, the number of germinal cells per 100 Sertoli cells was calculated (Davies et al., 1974). The resultant means are given in Table 3. There were significant overall effects of treatment of step 16 and step 7 spermatids and pachytene spermatocytes $(P<0.01$ in each case) and on type A spermatogonia $(P<0.05)$. There were decreased numbers of all types of germ cells in Groups C and D and the decreases were greater in Group E.

The ratios of germinal cells showed that the only significant effect was on the ratio of step 16 to step 7 spermatids $(0.59 \pm 0.02 ; P<0.001)$. This indicates that 12 weeks of treatment with testosterone oenanthate inhibited maturation of spermatids between step 7 and step 16 .

\section{Discussion}

Testosterone was used in these experiments in two ways, first by itself to suppress gonadotrophin secretion and then for replacement therapy to maintain the accessory sex organs, libido and potency.

In mice treated with testosterone oenanthate, testicular weight declined and spermatogenesis was suppressed. This confirmed earlier reports that testosterone can suppress the seminiferous epithelium and reduce testicular weight in rats (Abdi \& Hasan, 1973; Walsh \& Swerdloff, 1973; Berndtson et al., 1974; Neumann, Diallo, Hasan, Schenck \& Traore, 1976; Flickinger, 1978). The scarcity of late germ cells must largely account for the reduced weight of the testis in treated mice.

In the present study the seminal vesicles hypertrophied because of high blood testosterone concentrations. The weight of the accessory sex glands (ventral prostate and seminal vesicles) was normal or nearly so in rats treated with doses of testosterone oenanthate or propionate sufficient to suppress spermatogenesis (Walsh \& Swerdloff, 1973; Neumann et al., 1976; Flickinger, 1978). These findings suggest that mice require a relatively higher dose than do rats of testosterone oenanthate to affect the testis.

Intratubular cells were counted in sections of tubules at stage VII of the cycle of the seminiferous epithelium. This stage was chosen because it contains two generations of primary spermatocytes (preleptotene and pachytene) and two generations of spermatids (step 7 and step 16) as well as type A spermatogonia. In the present study there were marked decreases in the number of all types of germinal cell at stage VII, but late spermatids were the cells most affected by testosterone oenanthate treatment. The number of Sertoli cells per tubule cross-section increased, presumably due to shrinkage and consequent shortening of tubules. Step 7 to step 16 spermatid maturation was inhibited. In rats Flickinger (1978) observed that more young spermatids and pachytene spermatocytes degenerated than other germinal cells. In the present experiment 12 weeks of treatment was insufficient to deplete the testis of all primary spermatocytes and spermatids. Similarly the final steps of spermatogenesis in the intact rat can be severely inhibited by administering an androgen, but it is very difficult to cause complete arrest at an earlier stage of spermatogenesis (Cunningham \& Huckins, 1980). The changes in the intratubular cells in mice resembled those occurring in rats after hypophysectomy (Russell \& Clermont, 1977) or after neutralization of LH with anti-LH serum 
(Dym \& Madhwa Raj, 1977), and were assumed to be due to suppression of LH and therefore of androgen secretion.

In the current investigations, serum testosterone concentrations were increased 3.5 times in mice $24 \mathrm{~h}$ after the last injection of testosterone oenanthate. Studies in the rat have shown that testosterone propionate $(1.0 \mathrm{mg} / \mathrm{kg}$ body weight/day s.c.) doubled the serum testosterone concentration for at least $8 \mathrm{~h}$ although the concentration at $24 \mathrm{~h}$ was normal or slightly lower than normal and the intratesticular testosterone concentrations was suppressed to $5 \%$ of control values (Cunningham \& Huckins, 1979). A similar effect on testicular testosterone content was obtained in men treated with $50 \mathrm{mg} /$ day (Morse, Leach, Rowley \& Heller, 1973).

The serum concentration of LH became undetectable and FSH was partly suppressed when a daily dose of $0.5 \mathrm{mg}$ testosterone $/ \mathrm{kg}$ body weight (Verjans, van der Molen \& Eik-Nes, 1975) or of $0.5 \mathrm{mg}$ testosterone propionate $/ \mathrm{kg}$ (Cunningham \& Huckins, 1979) was administered to rats. Administration of testosterone oenanthate to normal men ( $200 \mathrm{mg}$ weekly) suppressed both $\mathrm{LH}$ and FSH to very low or undetectable levels after 8 weeks. This degree of gonadotrophin suppression was due to the elevated serum concentration of testosterone, which increased by more than $120 \%$ during the first 3 days after an injection (Caminos-Torres, Ma \& Snyder, 1977) and was still $50-60 \%$ above the control level at 1 week after injection (Swerdloff, Palacios, McClure, Campfield \& Brosman, 1978). We conclude that testosterone oenanthate is not a suitable way of suppressing spermatogenesis as it increases the blood testosterone concentration.

M.R.B. was holder of a Commonwealth Scholarship from the Association of Commonwealth Universities, U.K.

\section{References}

Abdi, S.H.M. \& Hasan, W. (1973) Effect of testosterone on the histological structure of the testis of adult albino rats. Ind. J. med. Res. 61, 1207-1211.

Berndtson, W.E., Desjardins, C. \& Ewing, L.L. (1974) Inhibition and maintenance of spermatogenesis in rats implanted with polydimethylsiloxane capsules containing various androgens. J. Endocr. 62, 125-135.

Bustos-Obregon, E. (1970) On Sertoli cell number and distribution in rat testis. Archs Biol. 81, 99-108.

Caminos-Torres, R., Ma, L. \& Snyder, P.J. (1977) Testosterone-induced inhibition of the LH and FSH responses to gonadotrophin-releasing hormone. $J$. clin. Endocr. Metab. 55, 1141-1153.

Clermont, Y. \& Harvey, S.C. (1967) Effect of hormones on spermatogenesis in the rat. Ciba Fdn Colloq. Endcr. 16, 173-189.

Clermont, Y. \& Morgentaler, H. (1955) Quantitative study of spermatogenesis in the hypophysectomized rat. Endocrinology 57, 369-382.

Cunningham, G.R. \& Huckins, C. (1979) Persistence of complete spermatogenesis in the presence of low intratesticular concentrations of testosterone. Endocrinology 105, 177-186.

Cunningham, G.R. \& Huckins, C. (1980) Exogenous androgens: their potential for reversible contraception. In Regulation of Male Fertility, pp. 77-83. Eds G. R. Cunningham, W. B. Schill \& E. S. E. Hafez. Martinus Nijhoff, The Hague.

Davies, A.C. (1973) Estimation of number and diameter of isodimetric spherical particles in microtome sections. J. Microsc. 98, 79-83.
Davies, A.G., Courot, M. \& Gresham, P. (1974) Effects of testosterone and FSH on spermatogenesis in adult mice during treatment with oestradiol. J. Endocr. 60, $37-45$.

Desjardins, C., Ewing, L.L. \& Irby, D.C. (1973) Response of the rabbit seminiferous epithelium to testosterone administered via polydimethyl-siloxane capsules. Endocrinology 93, 450-460.

Dym, M. \& Madhwa Raj, H.G. (1977) Response of adult rat Sertoli cells and Leydig cells to depletion of $\mathrm{LH}$ and testosterone. Biol. Reprod. 17, 676-696.

Ewing, L.L., Stratton, L.G. \& Desjardins, C. (1973) Effects of testosterone polydimethylsiloxane implants upon serum production, libido and accessory sex organ function in rabbits. J. Reprod. Fert. 35, $245-253$.

Flickinger, C.J. (1978) Effects of testosterone enanthate on the structure of the male reproductive tract of rat. Anat. Rec. 192, 555-584.

Heller, C.G., Morse, H.C., Su, M. \& Rowley, M.J. (1970) The role of FSH, ICSH and endogenous testosterone during testicular suppression by exogenous testosterone in normal men. Adv. exp. Med. Biol. 10, 249-259.

Leblond, C.P. \& Clermont, Y. (1952) Spermiogenesis of rat, mouse, hamster and guinea pig as revealed by the "periodic acid-fuchsin sulfurous acid" technique. Am. J. Anat. 90, 167-215.

Ludwig, D.J. (1950) The effect of androgen on spermatogenesis. Endocrinology 46, 453-481.

McManus, J.F.A. (1946) Histological demonstration of mucin after periodic acid. Nature, Lond. 158, 202. 
Morse, H.C., Leach, D.R., Rowley, M.J. \& Heller, C.G. (1973) Effect of cyproterone acetate on sperm concentration, seminal fluid volume, testicular cytology and levels of plasma and urinary ICSH, FSH and testosterone in normal men. J. Reprod. Fert. 32, 365-378.

Nelson, W.O. \& Merckel, C. (1937) Maintenance of spermatogenesis in testis of the hypophysectomised rat with sterol derivatives. Proc. Soc. exp. Biol. Med. 36, 825-828.

Neumann, F., Diallo, F.A., Hasan, S.H., Schenck, B. \& Traore, I. (1976) The influence of pharmaceutical compounds on male fertility. Andrologia 8, 203-235.

Oakberg, E.F. (1956) A description of spermiogenesis in the mouse and its use in analysis of the cycle of the seminiferous epithelium and germ cell renewal. Am. J. Anat. 99, 391-414.

Reddy, P.R.K. \& Rao, J.M. (1972) Reversible antifertility action of testosterone propionate in human males. Contraception 5, 295-301.

Russell, L.D. \& Clermont, Y. (1977) Degeneration of germ cells in normal hypophysectomized and hormone treated hypophysectomized rats. Anat. Rec. 187, 347-366.
Steinberger, E. \& Smith, K.D. (1977) Testosterone oenanthate: a possible reversible male contraceptive. Contraception 16, 261-268.

Swerdloff, R.S., Palacios, A., McClure, R.D., Campfield, L.A. \& Brosman, S.A. (1978) Clinical evaluation of testoterone enanthate in the reversible suppression of spermatogenesis in the human male: efficacy, mechanism of action and adverse effects. In Hormonal Control of Male Fertility pp. 41-54. Ed. D. J. Patanelli. Government Printing Office, Washington DC.

Verjans, J.L., van der Molen, H.J. \& Eik-Nes, K.B. (1975) Relation between circulating levels of testosterone, LH and FSH in intact and castrated adult male rats after testosterone administration. Acta endocr., Copenh. 79, 380-386.

Walsh, P.C. \& Swerdlof, R.S. (1973) Biphasic effect of testosterone on spermatogenesis in the rat. Invest. Urol. 11, 190-193.

Received 20 January 1986 